\section{Considering urban green space and informal backyard rentals in South Africa: Disproving the compensation hypothesis}

\author{
Louis Lategan \& Juaneé Cilliers
}

http://dx.doi.org/10.18820/2415-0495/trp69i1.1

Peer reviewed and revised November 2016

\begin{abstract}
This research reflects on planning for urban green space and the related impact of informal backyard rental densification in South Africa, based on the 'compensation hypothesis'. Informal backyard dwellings may increase densities substantially, occupying private green space, but often without reciprocal increases in public urban green space area. According to the compensation hypothesis, residents with limited access to private green space are more likely to seek compensation elsewhere. This research employs qualitative and quantitative analyses to investigate access to, and use of green spaces in the Bridgton and Bongolethu townships, Oudtshoorn. Findings disprove the compensation hypothesis, showing that proximate public green spaces are used sporadically, not correlating to increased densities. The number of backyard dwellings does not result in compensation behaviour, but an increased number of backyard tenants affect perceptions of green space availability and privacy. Although the compensation hypothesis is disproved in this case, findings probe the need to reconsider urban green space planning within low-cost areas, particularly considering densification impacts, linked to quality of life. As such, accessibility to public green spaces, as well as their function and form should be questioned as part of broader spatial planning approaches.
\end{abstract}

Key words: Compensation hypothesis, ecosystem services, informal backyard rentals, urban green space

\section{OORWEEG STEDELIKE GROEN AREAS EN INFORMELE AGTERPLAAS-HUURVERDIGTING IN SUID-AFRIKA: WEERLÊ DIE VERGOEDINGSHIPOTESE}

Hierdie navorsing besin oor die beplanning van stedelike groen areas en die verwante impak van informele agterplaas-huurverdigting in Suid-Afrika, gebaseer op die 'vergoedingshipotese'. Informele agterplaaswonings kan digthede aansienlik verhoog en beset sodoende private groen ruimtes, dikwels sonder wedersydse toenames in openbare stedelike groen areas. Volgens die vergoedingshipotese sal inwoners met ' $n$ beperkte toegang tot private groen ruimte meer geneig wees om vergoeding elders te soek. Hierdie navorsing maak gebruik van kwalitatiewe en kwantitatiewe metodes om toegang tot, en gebruik van groen areas in die Bridgton- en Bongolethu-areas van Oudtshoorn te ondersoek. Bevindinge weerspreek die vergoedingshipotese en dui daarop dat openbare groen ruimtes hier sporadies gebruik word, dus nie korreleer met verhoogde digtheid nie. Die aantal agterplaaswonings lei nie tot vergoedingsgedrag nie, maar ' $n$ toename in die aantal agterplaashuurders beïnvloed wel persepsies van groen ruimte beskikbaarheid en privaatheid. Hoewel die vergoedingshipotese in hierdie geval weerspreek word, toon bevindings die noodsaaklikheid om stedelike groen-ruimte-beplanning te heroorweeg binne die konteks van lae-koste gebiede, veral met inagneming van die verdigtingsimpak, gekoppel aan lewenskwaliteitoorwegings. As sodanig moet toeganklikheid tot openbare groen ruimtes, asook die funksie en vorm daarvan bevraagteken word as deel van breër ruimtelike beplanningsbenaderings.

Sleutelwoorde: Ekosisteem dienste, informele agterplaasverhuring, stedelike groen spasie, vergoedingshipotese

\section{TEKOLOBOTJHA YA MOHOPOLO WA HO LEFA (HO BUSELLETSA): MORERO WA DIBAKA TSE TALA TSA TOROPO LE KHIRO E SENG MOLAONG YA MATLO A KA MORAO DIJARETENG AFRIKA BORWA}

Atikele ena ke ya pele ya ho totobatsa ka botlalo morero wa dibaka tse tala tsa toropo le tshebediso mabapi le khiro e seng molaong ya matlo a teteaneng a ka morao dijareteng Afrika Borwa, e itshetlehile hodima mohopolo wa ho lefa (ho buselletsa). Tlhophollo ya lebadi le boleng (Qualitative and quantitative analyses) thutong ya thaloso ya makeishene a Bridgton le Bongolethu Oudtshoorn, e fana ka bopaki bo lekotsweng, bo tsepamisitseng maikutlo hodima katamelo le tshebediso ya dibaka tse tala tsa batho bohle, mekgwa ya selehae/ e tlwaelehileng ya ho sebetsa serapeng/dirapeng le khiro e seng molaong dijareteng tse ka morao matlong. Diphumano ha di dumellane le mohopolo wa ho lefa (ho buselletsa). Thutong ena ya thaloso, dibaka tse tala tsa batho bohle, tse leng haufi; ha di sebediswe kgafetsa/hangata, bana ba bapalla dibakeng tse ka pele le tse ka morao matlong. Palo ya bodulo matlong a ka morao dijareteng le kgopolo ya hore dibaka tsa kantle di lekantswe, ha di bontshe kamano; le ha ho le jwalo, palo e eketsehileng ya bahiri ba dulang dijareteng tse ka morao matlong e ama maikutlo tabeng ya dibaka tsa kantle tse lekantsweng le bonnotshi thutong ena ya thaloso. Diphumano di hatella thokeho ya ho kgothalletsa tshebediso e ntle ya dibaka tse tala tsa batho bohle, ho lokisa ditshitiso bakeng sa ho fihlella le ho laola kgonahalo ya kotsi ya kamano ya dintho bophelong (ecosystem) ditjhabeng tse fumanang moputso o tlase, moo khiro e seng molaong dijareteng tse ka morao matlong e tlwaelehileng.

\section{INTRODUCTION}

Urban green space, as part of urban green infrastructure (Tzoulas Korpela,

The authors declare no conflict of interest to this title or article.

Louis Lategan, Unit for Environmental Sciences and Management, North-West University, Potchefstroom, 2520, South Africa. Phone: 0720141181, email: <latlou.info@gmail.com>

Prof. Juanee Cilliers, Unit for Environmental Sciences and Management, North-West University, Potchefstroom, 2520, South Africa. Phone: 0834143939, email: <juanee.cilliers@nwu.ac.za> 
Venn, Yli-Pelkonen, Kaźmierczak \& Niemela 2007: 139; Harrison, Bobbins, Culwick, Humby, La Mantia, Todes \& Weakley, 2014: 67; Nolon, 2016: 1), is an invaluable resource in any human settlement, delivering various life-sustaining services (MEA, 2005; Daily, Polasky, Goldstein,

Kareiva, Mooney, Pejchar, Ricketss, Salzman \& Shallenberger, 2009: 21; Cilliers \& Cilliers, 2015: 1; Cilliers \& Cilliers, 2016: 9; Lindemann-Matthies \& Brieger, 2016: 33). As such, this article departs by defining urban green space and unpacking related services, invoking the concepts of ecosystem services and disservices, and exploring related environmental, economic and social benefits. Whilst the significance of urban green space in terms of ecosystem services, environmental, economic and social benefits has been recognised for some time (Costanza, d'Arge, De Groot, Farber, Grasso, Hannon, Limburg, Naeem, O’Neill, Paruelo, Raskin, Sutton \& Van den Belt, 1997; Bolund \& Hunhammar, 1999; Kabisch, 2015: 557), urban green space remains an endangered resource, vulnerable to urbanisation pressures and attempts to densify and consolidate human settlements (Barbosa, Tratalos, Armsworth, Davies, Fuller, Johnson \& Gaston, 2007: 187; McConnachie \& Shackleton, 2010: 245; Chen \& $\mathrm{Hu}, 2015$ : 33; Haaland \& Van den Bosch, 2015: 760; Kabisch, Qureshi \& Haase 2015: 26). This article explores this vulnerability in South Africa's low-income housing context, as the country is recognised as one of the most urbanised countries in Africa, with an estimated $73.3 \%$ of the population to be urbanised by 2030 , in addition to a crippling housing demand, currently projected at 2.3 million units (Turok \& Borel-Saladin, 2014: 5). The results of such development pressures are varied, primarily defined by informal settlements, state-subsidised housing projects that display relatively low levels of urban green space provision, and the informal backyard rental sector. The informal backyard rental sector has become a prolific and growing component of South Africa's postapartheid housing landscape (Rubin
\& Gardner, 2013: 28; Shapurjee, Le Roux \& Coetzee, 2014: 20). Informal backyard rentals have substantially increased both population and dwelling unit densities across the country (Shapurjee \& Charlton, 2013: 663; Turok \& Borel-Saladin, 2015: 5; Lategan \& Cilliers, 2016), densifying backyard gardens in historic townships and new subsidised housing projects. These unsanctioned densification practices have continued without policy guidance (Lemanski, 2009: 475; Tshangana, 2013: 10), and have gained relatively little traction from researchers (Turok \& Borel-Saladin, 2015: 10). Urban green space planning and use is one aspect that has been especially neglected in relation to informal backyard rentals.

This research is the first of its kind to explicitly address urban green space planning and use with regard to informal backyard densification in South Africa. In particular, this article reflects on the 'compensation hypothesis' (Maat \& De Vries, 2006) and its relevance within the local context. The compensation hypothesis, as a relatively rudimentary concept, is defined accordingly. There is a general understanding that increased densities and any subsequent loss of private green space may be equalised by increasing access to public green space (Maat \& De Vries, 2006; Lin, Meyers \& Barnett, 2015: 953). Thus, in terms of the compensation hypothesis, it is understood that residents will compensate poor access, or, in the context of this article, reduced area of private green space with access to public green space (Byrne \& Sipe, 2010: 4). The hypothesis is tested in this article, as it has not been proven consistently elsewhere (Maat \& De Vries, 2006; Grose, 2009; Byrne \& Sipe, 2010), and may have significant impacts in terms of future policy planning with informal backyard densification in mind. This article draws on research conducted in a case study of the Bridgton and Bongolethu townships in the town of Oudtshoorn, where households surrounding a large urban green space, as the Bridgton Pavilion, were subjected to a questionnaire that probed access to, and use of public green space, domestic gardening trends and the impacts of informal backyard rentals. Results are discussed under Section 4 of the article. These findings are used to test the compensation hypothesis and draw ultimate conclusions.

\section{LITERATURE REVIEW}

\subsection{Coming to terms with urban green space, related services and benefits}

This article defines urban green space, following Chen and $\mathrm{Hu}$ (2015: 33), as all land covered by vegetation within the urban environment. This broad definition first includes those green spaces classified as public green space, exemplified by parks, playgrounds, botanical gardens, sporting fields, as well as pockets and corridors of natural and semi-natural vegetation accessible to the public and owned by public authorities (Comber, Brunsdon \& Green, 2008: 103; Houssay-Holzschuch \& Teppo, 2009: 353; Byrne \& Sipe, 2010: 10; You, 2016: 176). Secondly, the definition includes private urban green space, as domestic gardens and allotments, where access is restricted by private ownership (Kabisch et al., 2015: 25; Mosina \& Maroyi, 2016: 181; You, 2016: 176). Thirdly, the definition includes generally unconsidered spaces such as vacant stands, railway sidings, utility easements, corridors between buildings and canal sides that are often overgrown with spontaneous vegetation (Ward-Thompson, 2002; Rupprecht \& Byrne, 2014: 597). Whilst all three categorisations are recognised as components of an urban green space network, this article focuses specifically on those urban green spaces deliberately established by planners through urban design, layout and zoning categories to accommodate desired land uses. In this regard, this article engages primarily with the first two categories, as urban green spaces intended to provide amenity, or recreational uses (Cilliers \& Cilliers, 2016: 12) in the case study, as public 
green spaces including the Bridgton Pavilion and local playgrounds, and the private green spaces constituted by domestic gardens.

Public and private green spaces provide both shared and unique functions within the urban environment, providing urbanites with primary contact with biodiversity and the natural environment (Barbosa et al., 2007: 187). The quality of such spaces may vary significantly, gauged according to the subjective ideals, expectations and perceptions of those who regularly use them. The quality of public green spaces is of specific concern to planners, as they are directly impacted by their design and policy decisions. As minimum quality considerations, public green spaces may be expected to deliver on basic requirements of size, amenity, vegetation cover, safety, social opportunities, maintenance and appearance, as generally influenced by the public authorities who own them. Where expectations on such requirements are exceeded, perceptions on quality may increase in return. Quality is paramount, as some argue that quality and not quantity of urban green space is most important in planning for such spaces (Haaland \& Van den Bosch, 2015: 766). In addition, the level of access provided to prospective users of public green space is an essential consideration. Various standards have been developed globally to guide appropriate area of, and distance to the nearest public green space (Barbosa et al., 2007: 187; Byrne \& Sipe, 2010: 21; McConnachie \& Shackleton, 2010: 247). Elaborating on detailed standards falls beyond the scope of this article. It is important to acknowledge that such guidelines exist, and that contextualized variances may make the extrapolation of such standards inappropriate. Furthermore, studies have shown that physical accessibility, as proximity, is often favoured as an accessibility measure, whilst perceived access may, in fact, be more significant than geographic proximity (Wan \& Shen, 2015: 93). Perceptions on access to urban green space may depend on issues such as admission charges, operating hours, social constraints, or physical barriers such as walls and fencing. Notwithstanding such obstacles, public green spaces are still regarded as public goods accessed more freely by the community as a whole (Haaland \& Van den Bosch, 2015: 765; You, 2016: 176).

Public green spaces are often viewed through a social lens as physical spaces in which diverse people meet and interact in surroundings that provide facilities and services they could not access without public aid (Bernardini \& Irvine, 2007; Houssay-Holzschuch \& Teppo, 2009: 353). Public green spaces may be especially valued by those who cannot access private green space, with those public spaces that are more intimate and familiar and part of daily routines being most valued (Bernardini \& Irvine, 2007; Coolen \& Meesters, 2012: 52). Private green spaces, or domestic gardens, conversely hold several meanings related to escapism, identity and ownership, and are regarded as places of control, retreat, creativity, privacy, relaxation and freedom (Francis, 1990; Bhatti \& Church, 2000; Gross \& Lane, 2007; Coolen \& Meesters, 2012: 52). Private green space depends on stand sizes conducive to the establishment and maintenance of aesthetically pleasing and productive domestic gardens (McConnachie \& Shackleton, 2010: 244) that may provide home owners and the broader community with certain services and benefits, also directly related to urban design and planning policies.

Urban green spaces are often considered part of urban green infrastructure (Lubbe, Siebert \& Cilliers, 2010: 2901; Cilliers \& Cilliers, 2016:10; Nolon, 2016: 1), as "all natural, semi-natural and artificial networks of multifunctional ecological systems within, around and between urban areas, at all spatial scales" (Tzoulas et al., 2007: 169), that provide specific functions, managed with the aim of conserving ecosystem values and providing associated benefits to human populations (Hoctor, Carr,
Zwick, Huntley, Smith, Maehr, Buch \& Hilsenbeck, 2008: 92). Accordingly, urban green spaces may play a significant part in supporting urban communities in ecological and social terms (Barbosa et al., 2007: 192; Kabisch et al., 2015: 26), substituting grey infrastructure services and expenses, effectively counteracting many of the negative environmental impacts levied by urbanisation (Chen \& Hu, 2015: 32), and advancing sustainability (Byrne \& Sipe, 2010: 7). Such services are often conceptualised around the 'ecosystem services' (ES) approach, with ecosystem services defined as ecosystem goods and services representing the benefits that human populations derive, directly or indirectly, from ecosystem functions (Kremen \& Cowling, 2005: 468; Cilliers, Cilliers, Lubbe \& Siebert, 2013: 682; Haaland \& Van den Bosch, 2015: 760). Urban green space has been singled out as the most significant environmental resource available to planners through which green infrastructure and related ecosystem services and benefits may be accommodated via the range of planning instruments available to establish such spaces.

When this resource is mindfully designed and managed, inherent ecosystem services and related benefits may be harnessed and augmented (Byrne \& Sipe, 2010: 9; Lin et al., 2015: 952). In more detail, such ecosystem services may include environmental benefits such as climate mitigation, air and water filtration, improved carbon sequestration, energy conservation, wind and noise filtration, promoting biodiversity and providing natural habitat, storm-water attenuation and flood mitigation, enhancing watertable catchment and erosion control (Byrne \& Sipe, 2010: 9; Ward, Parker \& Shackleton, 2010: 49; Odindi \& Mhangara, 2012: 653; Chen \& Hu, 2015: 32; Kabisch et al., 2015: 26; Lin et al., 2015: 952; Cilliers \& Cilliers, 2016: 17; Mosina \& Maroyi, 2016: 181; Nolon, 2016: 1).

In addition to these environmental and social benefits, certain tangent economic/financial benefits may also be realised in relation to such 
ecosystem services. These benefits may include reducing services expenditure and maintenance costs, reducing health-care expenses, generating income via tourism and related revenue streams, increased retail sales, improved marketability, increased production, augmented neighbourhood values and increased recoupable tax revenue, the last facilitated by the effects urban green spaces may have on property value, with increased real estate values generally attributed to properties located next to, or within the proximity of urban green space affecting tax revenue and property sales (Byrne \& Sipe, 2010: 9; Cilliers et al., 2013: 684; Kabisch et al., 2015: 26; Cilliers \& Cilliers, 2016: 16; Nolon, 2016: 1). It should also be noted that the association between increased real-estate prices and proximate location to urban green space has not been proven consistently. ${ }^{1}$ In addition, urban green spaces may provide several social benefits (Tengberg, Fredholm, Eliasson, Knez, Saltzman \& Wetterberg, 2012: 16; Cilliers et al., 2013: 693; Chen \& Hu, 2015: 32; Haaland \& Van den Bosch, 2015: 760; Kabisch et al., 2015: 26), inter alia, providing locales for social interaction and a shared focus to diverse communities and neighbourhoods in support of social integration (Odindi \& Mhangara, 2012: 653), social cohesion (Mosina \& Maroyi, 2016: 181), and assimilating values and moral attitudes (Barbosa et al., 2007: 187; Cilliers \& Cilliers, 2016: 17).

Social gains are accommodated, as public green spaces attract users through the recreational opportunities provided (Ward et al., 2010: 49; Cilliers et al., 2013: 683; Mosina \& Maroyi, 2016: 181), or the prospect of access to nature (McConnachie \& Shackleton, 2010: 244) and/or aesthetically pleasing surroundings where identity of space, sense of place and liveability are enhanced (Cilliers \& Cilliers, 2016), and opportunities for reflection, access to cultural heritage and identity, spiritual enrichment; cognitive, emotional and social development

1 For a South African example, see Cilliers et al. (2013). provided (MEA, 2005; Tengberg et al., 2012: 16). As such, urbanites who access urban green space may improve both their mental and physical health related to the potential to reduce health expenses noted previously (Barbosa et al., 2007: 187; Tzoulas et al., 2007: 168; Byrne \& Sipe, 2010: 9; Haaland \& Van den Bosch, 2015: 760; Kabisch et al., 2015: 26; Lin et al., 2015: 956; Wan \& Shen, 2015: 93). It is further important to recognise that many of the social and psychological advantages provided by urban green space are not necessarily dependent on direct physical access to such venues. Even viewing greenery may provide restorative opportunities and establish more stable domestic environments (Byrne \& Sipe, 2010: 22).

\section{When considering ecosystem} services, it is also apt to acknowledge certain damages on the other side of the spectrum, termed ecosystem disservices. Ecosystem disservices, through which "the same natural functions and structures that provide beneficial services in urban areas are also responsible for detrimental disservices" (von Döhren \& Haase, 2015), may have negative effects on wellbeing (Cilliers et al., 2013: 683). Ecologically speaking, ecosystem disservices may include the establishment of invasive species that overrun urban green space to the detriment of indigenous species and systems, influencing populations, community interactions, abiotic variables, and ecosystem processes (Charles \& Dukes, 2007: 233;

Lyytimäki \& Sipilä, 2009: 310) as well as the production of volatile organic compounds (VOCs) that decrease air quality (Escobedo, Kroeger \& Wagner, 2011; von Döhren \& Haase, 2015). Ecosystem disservices in the social realm may include safety and security concerns (Cilliers et al., 2013: 696), for example, when urban green spaces provide venues for illicit activity, discord, nuisance or health impacts such as allergy attacks, safety hazards from tree falls, habitats for poisonous plants and pests, and opportunities for littering (Lyytimäki, Petersen, Normander \& Bezák, 2008: 165; von Döhren \& Haase, 2015: 491; Cilliers \& Cilliers, 2016: 9).
Where the economic impacts of ecosystem disservices are considered, damage caused to infrastructure by tree roots, preventing more profitable uses for the sake of maintaining green space, and constant maintenance costs, may be included (Lyytimäki et al., 2008: 166). Another tangent negative outcome may be considered in the risk of gentrification and dislocation. As provided earlier, access to urban green space may increase property value. Where urban greening projects are instituted and property prices in proximity to newly established or upgraded public green spaces increased, gentrification may take place (Dale \& Newman, 2009: 672), through which lower income residents may be unfairly displaced. Low-income communities require especially sensitive approaches to urban green space planning in order to address potential ecosystem disservices and general accessibility issues. Lower income groups are less likely to access distant urban green space, given the cost of transportation, entrance fees and other expenses such visits may require (Haaland \& Van den Bosch, 2015: 765; Kabisch et al., 2015: 26). As such, lower income groups need improved access to urban green space within their immediate areas (Byrne \& Sipe, 2010:4).

Despite such realisations, inequitable access to urban green space remains a common feature of urban life across the globe, between different cities and within them (Byrne \& Sipe, 2010: 7; Kabisch \& Haase, 2014; Chen \& Hu, 2015: 32; Haaland \& Van den Bosch, 2015: 764; You, 2016: 176), often based on socioeconomic variables such as wealth, education and race (McConnachie \& Shackleton, 2010: 244; Cilliers et al., 2013: 693; Lin et al., 2015: 953; You, 2016: 178). In South Africa, such variables are conflated as a result of the country's colonial and more recent apartheid past, with race continuing to represent a significant determinant of access to urban green space. The following section provides some insight into urban green space provisions in South Africa, highlighting persistent inequalities. 


\subsection{Urban green space and South Africa's low-income communities}

During apartheid, suburbs designated for the privileged White population were pleasant and green, resembling the well laid-out, adequately serviced and maintained leafy suburbs found in the developed world. Impoverished African and Coloured urban and homeland townships, on the other hand, were left bleak and poorly serviced with a high proportion living in informal settlements (shanty towns) and informal backyard lodgings (Houssay-Holzschuch \& Teppo, 2009: 351; McConnachie \& Shackleton, 2010: 245). Such inequalities have remained ingrained in the post-apartheid era, despite efforts to redress past injustices through low-cost housing projects. Subsidised low-cost housing units have been delivered in staggering volumes across the country (Robins, 2002: 525; Shapurjee et al., 2014: 20), following the Reconstruction and Development programme of 1994 (RDP) (RSA, 1994) and the 2004 Breaking New Ground Strategy for Sustainable Human Settlements (BNG) (RSA, 2004). Green-space planning in these low-income suburbs, as for the rest of South Africa, is guided by Habitat and Local Agenda 21 initiatives, the Green Paper on Development Planning (1999), the National Environmental Management Act (Act 107 of 1998), and Spatial Development Frameworks (SDFs) (Cilliers et al., 2013: 696), among other instruments and guidelines. Despite commitments to sustainable development and redressing past injustices and inequalities, disparities in access to urban green space remain.

As such, former homeland towns, urban townships and RDP settlements continue to present fewer green spaces of lower quality and fewer street trees compared to more affluent urban areas (Gwedla \& Shackleton, 2015: 17). McConnachie and Shackleton (2010: 247), for example, found that public green area per RDP household is nearly five times less than in older township areas and 15 times less than in more affluent suburbs. Public green space provisions are severely limited in low-income housing projects. Green land uses compete against other land uses, constrained budgets and limited human resources prevent increased provisions of green spaces considered a luxury and not a priority (Cilliers et al., 2013: 694; Cilliers \& Cilliers, 2016: 22). In addition to lower proportions of public green space, RDP settlements and older townships, in particular, tend to display increased densities, further reducing the green space available to each household (McConnachie \& Shackleton, 2010: 246). Densities are augmented exponentially by the addition of informal backyard rental accommodation (Gardner, 2009: 14; Shapurjee \& Charlton, 2013: 663; Tshangana, 2013: 12).

\subsection{South African shanty towns, informal backyard rentals and environmental considerations}

Post-apartheid South Africa has witnessed significant growth in informal settlements (Gilbert, Mabin, McCarthy \& Watson, 1997: 134; Durand-Lasserve \& Royston, 2002: 3-4). As elsewhere, open green spaces, but not always on the urban periphery, are often besieged in these informal conquests (McConnachie \& Shackleton, 2010: 245; Haaland \& Van den Bosch, 2015; Odindi \& Mhangara, 2012: 653). Whilst Huchzermeyer (2009: 63) states that such land grabs are generally limited to areas where settlements may be less opposed and settlers regard themselves as least invasive, informal settlements inevitably exert severe environmental impacts due to their inappropriate locations. These impacts may include air pollution, littering and dumping, surface and groundwater contamination, disturbing fragile ecosystems such as aquifers, forests, estuarine or wetland areas, deforestation and land degradation, removing natural defence systems against floodwaters and storms (Ferguson, 1996: 171; Napier, 2002: 16; Goebel, 2007: 297; DEAT, 2015). Effects may be especially harsh where shanty towns are established on ecologically sensitive parcels or land of agricultural value (Morange, 2002: 11), where the loss of green space may be very invasive indeed (Napier, 2002: 20; Kilian, Fiehn, Ball \& Howells, 2005: 4). Yet, we should not regard the loss of fertile farmland and other green resources as penalties restricted to the informal housing sector alone. Formal lowdensity residential developments may be equally, if not more, responsible for such losses in South Africa, especially when land of agricultural value is considered (Geyer, Schloms, Du Plessis \& Van Eeden, 2011: 41).

Given market dynamics, the lowdensity, low-income housing projects noted in the previous section are habitually located on the urban periphery (Goebel, 2007: 292; Lategan, 2012; Klug, Rubin \& Todes, 2013: 668; Turok, 2013: 169; Chobokoane \& Horn, 2015: 3). Along with the unfavourable locations secured for these residential developments, additional impacts are levied once they have been established. The emergence of informal backyard rental dwellings are of particular concern in this regard. An informal backyard rental dwelling is defined as an informal structure erected by a property owner or tenant within the boundaries of a formally registered property that contains at least one formal dwelling unit. The materials and construction practices used do not comply with National Norms and Standards with the structure constructed attached or adjacent to an existing formal dwelling with partial or full access to the basic services provided to the main dwelling (Gilbert et al., 1997: 140; Crankshaw, Gilbert \& Morris, 2000: 852; Morange, 2002: 11; Gardner, 2009: 5). Though "there is a dearth of current, accurate data on backyarding in South Africa" (Rubin \& Gardner, 2013: 79) as census and statistical indicators vary (Carey, 2009: 8; Watson, 2009: 4), it is generally agreed that informal backyard rentals have become a major housing submarket in South Africa (Tshangana, 2013: 2). The proportion of people accommodated in informal backyard dwellings is growing 
faster than the proportion housed in shanty towns (Lemanski, 2009: 473; Govender, Barnes \& Pieper, 2011a: 336). By 2014, in excess of 756,000 informal backyard rental households were recorded (StatsSA, 2014), thus densifying low-income suburbs exponentially in terms of both dwelling unit and population densities (Poulsen \& Silverman, 2005: 23; Shapurjee \& Charlton, 2013: 663; McGaffin, Cirolia \& Massyn, 2015: 63).

Densification is generally revered as an instrument of sustainable urban development, bolstered by planning paradigms such as "new urbanism" (McConnell \& Wiley, 2010: 3; Sivam \& Karuppannan, 2012: 6), "the compact city" (Gardner, 2009: 9) and "smart growth" (Brunner, 2012: 7; Sivam \& Karuppannan, 2012: 2; Rubin \& Gardner, 2013: 20). In accordance with such shifts in planning thought, official densification strategies have regularly been employed to convert open land to residential use by means of infill development (Kabisch et al., 2015: 26) generally focused on available open space within the urban envelope. Such spaces are often unplanned for areas covered by vegetation or more formal public green spaces regarded as underutilised. By contrast, informal backyard infill densifies private property through unsanctioned and illegal mechanisms in which authorities play no part. Informal densification practices hold several benefits closely related to the motivations that drive formal infill strategies, but also present certain challenges. In this regard, South African scholars have recognised the potential of informal backyard rentals in providing the necessary population thresholds to support well-located social amenities and effective infrastructure and service delivery whilst offering backyard tenants proximate access to basic services in affordable rental shelter (Morange, 2002: 11; Poulsen \& Silverman, 2005: 20; Carey, 2009: 17; Gardner, 2009: 16; Lemanski, 2009: 477; Rubin \& Gardner, 2013: 21; Shapurjee \& Charlton, 2013: 663; Lategan \&
Cilliers, 2016). By contrast, some challenges include additional pressure on often already stressed infrastructural capacity, resulting in reduced connections and service access opportunities, increased fire and health risks as well as reduced private and backyard space (Lemanski, 2009: 477; Govender et al., 2011a: 341; Govender, Barnes \& Pieper, 2011b: 23; Rubin \& Gardner, 2013: 20; Tshangana, 2013: 7). The last is of specific concern in the context of this article. Even formalised infill densification strategies rarely give any further consideration to green space development in compensation for the greenery lost (Kabisch et al., 2015: 26). It is not surprising that, in South Africa, the loss of domestic garden space, due to informal backyard densification, suffers under the same negligence, propagated within a national policy vacuum that has discounted the entire informal backyard rental sector to date (Watson, 2009: 9; Shapurjee et al., 2014: 19). Within this laxity, counteracting the loss of valuable vegetation and trees in private gardens, as a consequence of infill, remains a dubious proposition (Haaland \& Van den Bosch, 2015: 767). As a result, inequitable access to urban green space may be exacerbated, living standards and local environmental quality potentially compromised, resource demands possibly increased, and ecosystems services, related benefits and sustainability prospects negatively affected (Byrne \& Sipe, 2010: 4; Ward et al., 2010: 49; Kabisch et al., 2015: 26; Lin et al., 2015: 953).

Various authors have commented on the need to upgrade, or retrofit, the capacity of basic services and infrastructure in order to cope with the increased demand produced by the addition of informal backyard rentals (Carey, 2009: 17; Lemanski, 2009: 482). Within such arguments, urban green spaces are rarely referenced explicitly, with authors such as Rubin \& Gardner (2013: 81), for example, simply noting the need to retrofit "social facilities". Another strong theme in the literature on addressing informal backyard rentals is the need to plan proactively for the generally inevitable emergence of informal backyard rental units in new low-cost housing projects within the primary phases of settlement planning in terms of service capacity, layout and urban design (Carey, 2009: 24; Gardner, 2009: 21; Watson, 2009: 11; Rubin \& Gardner, 2013: 72; Tshangana, 2013: 16; Shapurjee et al., 2014: 20). In this regard, calling for human settlement plans to integrate backyarding and make provision for environmental improvement initiatives and related investment opportunities, including provisions for "social services" (Tshangana, 2013: 16). Incurring extra capital cost will accommodate planned and desirable incremental backyard densification, without the need for modifications to service future capacity in established areas (Rubin \& Gardner, 2013: 23), where it may be impossible to add such services without significant redevelopment and evictions.

The following section investigates issues related to informal backyard rentals and urban green-space planning and use in such an established area, as a case study of the Bridgton and Bongolethu townships in the town of Oudtshoorn.

\section{EMPIRICAL INVESTIGATION}

\subsection{Case study: Introducing Oudtshoorn, Bridgton and Bongolethu}

The town of Oudtshoorn is the main seat of the Oudtshoorn Local Municipality (OLM), located within the Eden District Municipality (EDM) in South Africa's Western Cape province. Oudtshoorn is known globally as the epicentre of the ostrich-farming industry (Mambo, 2012: V; Wisner, Pelling, Macarenhas, Holloway, Ndong, Faye, Ribot \& Simon, 2015: 174) and has more recently become a major eco-tourism destination, given its location within the biodiverse fynbos and succulent Karoo biomes (Hoffman, Carrick, Gillson \& West, 2009: 54). Oudtshoorn is a place of dichotomy. Whilst neighbouring areas 
enjoy significant winter rainfalls, Oudtshoorn is located in a rain shadow, thus receiving markedly less precipitation. Yet, whilst the area has regularly battled extreme drought, torrential rains have also caused severe floods in the not too distant past. In addition, the climate is marked by extreme temperatures, ranging between $-2.1^{\circ} \mathrm{C}$ and $46.6^{\circ} \mathrm{C}$ (Mambo, 2012: 36; Wisner et al., 2015: 176). Dualities are not confined to the natural environment and climate, with the human settlements of Oudtshoorn, De Rust, Dysselsdorp and the rural hamlets that constitute the OLM showing marked disparities. The approximately 61,500 residents who reside in the town of Oudthoorn present significant divides and dualities, reflecting maintained apartheid inequalities. As such, the majority of Oudtshoorn's White residents $(12.49 \%$ of the population) have remained in the areas designated for them under apartheid rule, whereas the bulk of Black and Coloured residents $(86.46 \%)$ still call apartheid-era townships such as Bridgton and Bongolethu and the recently established informal settlement of Rose Valley home (Lategan \& Cilliers, 2013: 306; Wisner et al., 2015: 174) (see Figure 1).

In 2010, the sudden founding of the Rose Valley informal settlement on an environmentally sensitive parcel of land located on Oudtshoorn's eastern boundary (Lee, 2012) provided several research opportunities. A 2012 survey in the settlement indicated that $61 \%$ of the respondents had relocated from informal backyard lodgings in the townships of Bridgton and Bongolethu (Lategan, 2012). Given the relatively underresearched nature of South Africa's informal backyard rental sector (Lemanski, 2009: 474; Rubin \& Gardner, 2013: 7), the dearth of research on the subject focused on smaller municipalities (Zwaig, 2015: 2) and the neglect of established studies to recognise the impacts of informal backyard rentals on planning for urban green space, a case study within Bridgton/ Bongolethu was sought that could incorporate these elements. In a review of satellite imagery in 2013, one particular urban green space was accentuated, identified as the green heart of the community, given both its size and location within the area, as the Bridgton Pavilion (see Figures 1 and 2), described in greater detail throughout the article. Closer inspection revealed a significant number of informal backyard structures in the properties surrounding the Pavilion, thus meeting the criteria of presenting both public green space and proximate informal backyard dwellings for analysis.

\subsection{Methodology}

This research predominantly draws on two methods to inform the empirical investigation. First, the article references semistructured interviews conducted with selected officials in the OLM and other relevant experts, cited with pseudonyms throughout, who provided more nuanced information and supplemented shortcomings in the literature with regard to the local context. Secondly, data retrieved from a quantitative research survey distributed in the study area in 2013 provides statistical evidence. The survey was conducted by dispensing 101 questionnaires to residents of 101 properties surrounding the Bridgton Pavilion. Properties were included when home owners, or adult representatives, were home at the time of the survey and willing to participate. Prospective respondents were approached, informed of the purpose of the study and provided with general instructions. Informed consent was described in terms of the requirements of participation. Confidentiality statements and statements of voluntary participation

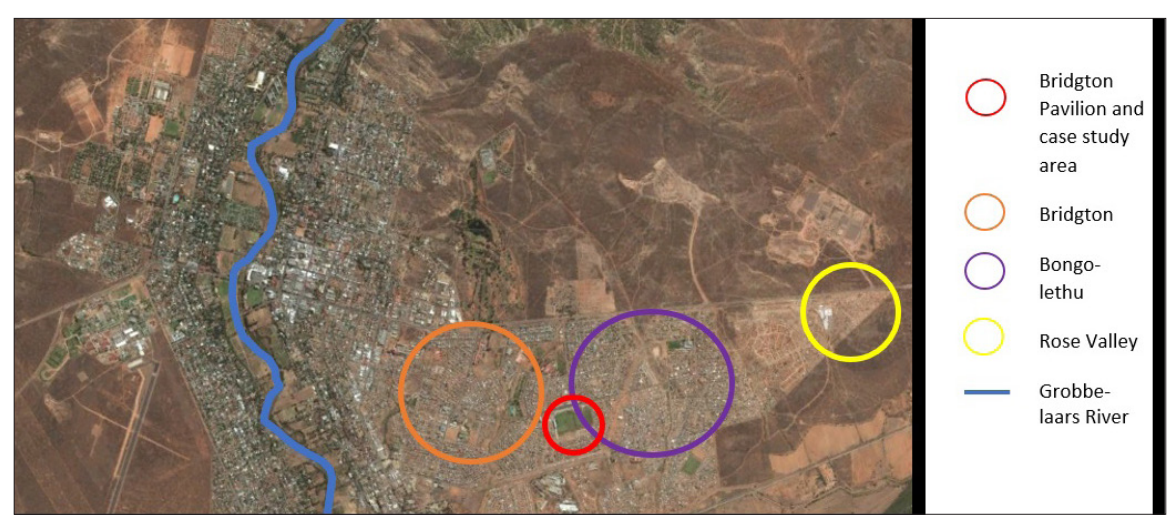

Figure 1: The town of Oudtshoorn and the Bridgton/Bongolethu case study

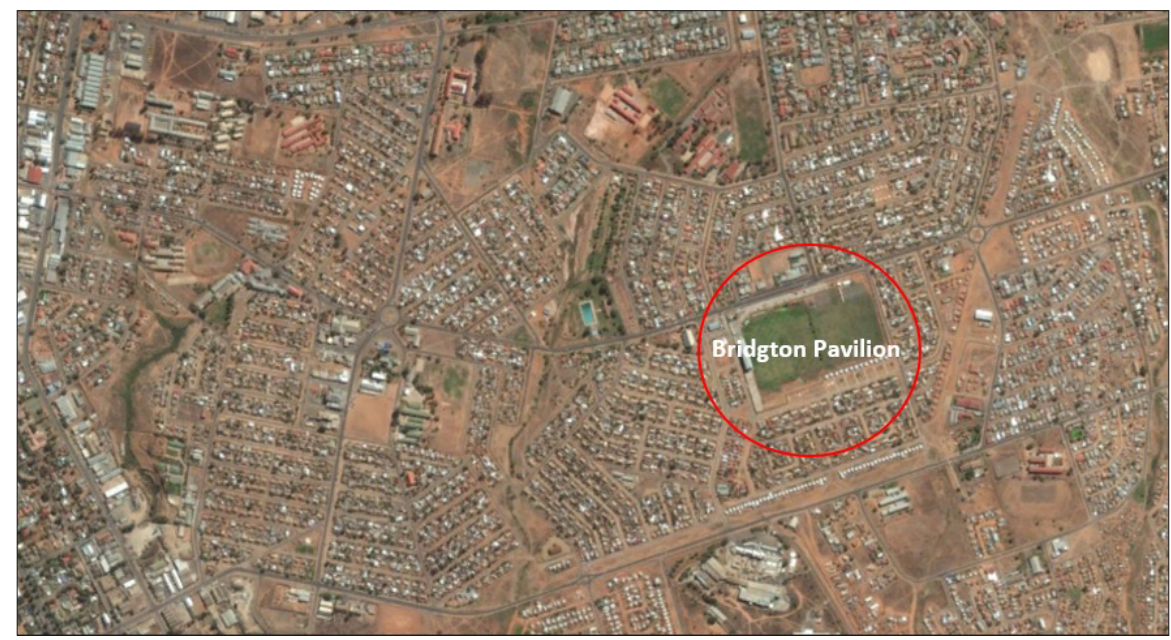

Figure 2: Aerial view of the Bridgton Pavilion and surrounding urban green space 
were also provided. Accordingly, the 101 questionnaires were distributed, based on convenience sampling, and a $100 \%$ return rate achieved. Convenience sampling is a nonprobability sampling technique where members of the target population meet certain practical criteria such as easy accessibility, geographical proximity, availability at a given time, or willingness to participate and are thus included (Dörnyei, 2007). Convenience sampling has various limitations due to its possible subjectivity in choosing the sample, but is especially useful when randomisation is impossible (Explorable.com, 2009), as in the case of Bridgton and Bongolethu townships in Oudtshoorn where surveys were conducted with the assistance of chaperones, supporting the researchers in terms of points of entry to the community. As such, limited time periods provided restrictions in terms of the availability of prospective participants and the necessity of including only respondents within proximity of the Bridgton Pavilion compelled convenience-sampling methods. There was no self-selection of respondents. It is doubtful that a random sample would have presented drastically different results, except in feasibly reducing the number of respondents, as there was no way of identifying which households would be both available and willing to participate from which to generate a random sample. It should be noted that the presence or absence of informal backyard rental components was not a determinant in respondent selection. Survey questions focused on respondents' access to, and use of public green space, domestic green space (gardening) trends and informal backyard rental particulars, where applicable. Questionnaires were drafted in collaboration with the North-West University's Statistical Consultancy Services, who also captured data and aided in statistical analyses and interpretation. As a convenience and not a random sample was used, $\mathrm{p}$-values are reported for the sake of completeness, but not interpreted.

\section{FINDINGS AND DISCUSSION}

This section discusses case study findings in two main subsections. The first reports on findings related to public green spaces, whereas the second focuses on domestic gardens in Bridgton and Bongolethu.

\subsection{Findings on public green spaces in the Bridgton/ Bongolethu case}

Respondent properties accommodated a total of 708 people, of whom $510(72 \%)$ were housed in formal dwellings and $198(27.96 \%)$ called informal backyard rentals home. In total, $53 \%$ of the respondent properties accommodated informal backyard rental structures, with a total of 71 informal backyard dwellings recorded. A Spearman's rank-order correlation ( $r$ ) was run to determine the relationship between number of informal backyard structures and number of informal backyard tenants. Results showed a strong positive and significant correlation $(r=0.867$, $p=0)$. A weaker positive correlation $(r=0.221, p=0.035)$ could also be established between the number of informal backyard tenants and the number of occupants in the main dwelling. The intensity of backyard activities uncovered increased both population and dwelling unit densities substantially (Lategan \& Cilliers, 2016), presenting an increase of $38.82 \%$ in the number of people who accessed basic services and public green space in the area.

The Bridgton Pavilion is the principal public green space in this part of town, followed by sporting fields attached to local schools and smaller playgrounds dispersed throughout the townships (see Figure 2). The Bridgton Pavilion presents an especially pertinent centre around which to concentrate research on urban green space in low-income communities, owing to the extensive refurbishment of its facilities and amenities in the recent past. The refurbishment process was largely instigated in the hopes of providing a quality green recreational space within an impoverished community that could host events to draw people from all tiers of Oudtshoorn society, according to an interview with Westen (2013). In terms of the use of the facility by those in direct proximity to the Bridgton Pavilion, survey findings suggest that $50.5 \%$ of the respondents claimed that they made increased use of the facility following its refurbishment; $27.7 \%$ claimed no change in regularity of use, and $21.8 \%$ reported using the facility less than previously. It should also be noted that, overall, $82.4 \%$ of the respondents made active use of proximate public green spaces, accepted as including, but not limited to the Bridgton Pavilion. In terms of regularity of use, respondents claimed to access such public green spaces, as captured in Figure 3.

Figure 3 shows that the majority of the respondents did not make routine use of proximate public green spaces. The high proportion of respondents claiming only 'occasional' and no use ('never') could be related to the restricted access provided to playgrounds and the Bridgton Pavilion, as detailed in the ensuing paragraph. In support, $68.3 \%$ of the respondents claimed that they could only access their closest public green space when public events were hosted there, whilst a contrasting $28.7 \%$ of the respondents claimed that proximate public green spaces were always accessible.

Statistical analysis showed that those claiming access to public green spaces only when attending public events, accessed these spaces only occasionally, whereas those who reported access at all times, only visited parks once a month.

This article posits that perceptions regarding perpetual access may be attributed more to the ingenuity and determination of users than to the real uninhibited access provided by these spaces. The Bridgton Pavilion is fenced with a corrugated metal wall; the majority of the other playgrounds have also been closed off, fenced, gated and even aggressively topped with razor wire. At the request of the community, playgrounds were enclosed to protect facilities from salvagers scavenging for steel and timber to 


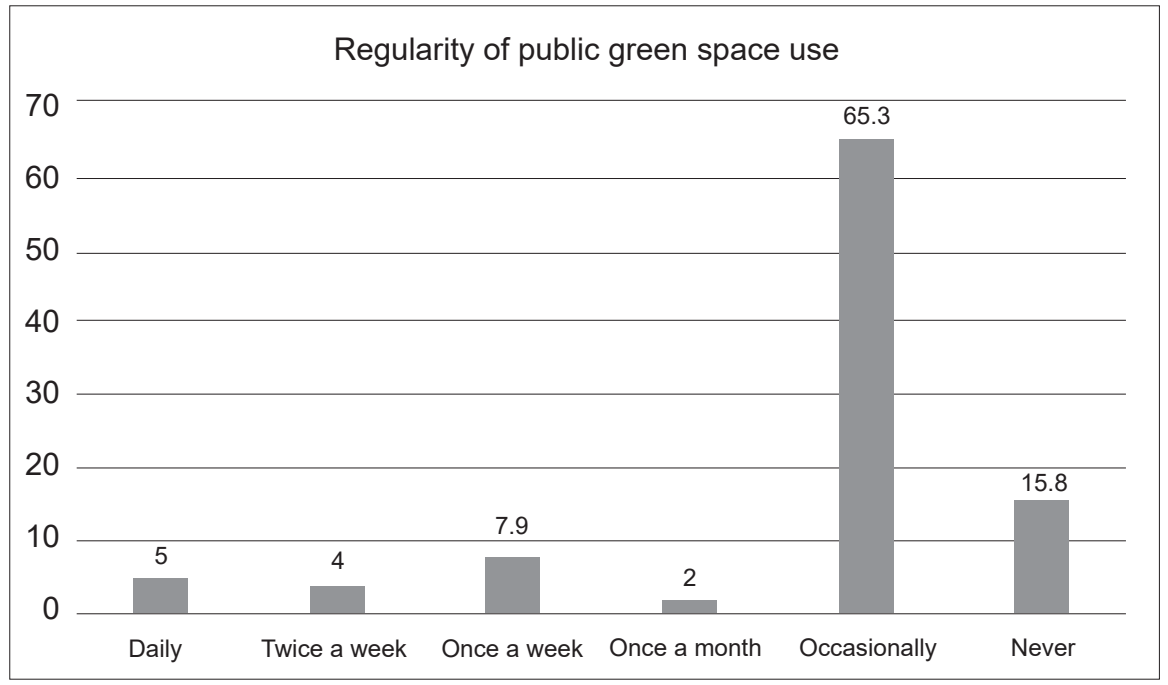

Figure 3: Regularity of public green space use sell or use in the construction of informal dwellings and to prevent criminals from meeting there, as expressed in interviews with Westen (2013) and Wire (2015). When public green spaces were accessible at any time, these facilities often became venues for gang meetings and drug abuse, understandably of considerable concern to residents, especially when the youth are considered (Captain, 2013). Data showed that $63.4 \%$ of the survey participants still rated substance abuse as a daily problem related to their nearest public green space. In and the nuisance factor, $67 \%$ of the respondents reported that they would ideally want to live within walking distance of a public green space, but not adjacent to it. In keeping with such disservices, only $2.6 \%$ of the respondents further declared urban green spaces as the primary venues used by their children for play. Anecdotally though, it must be noted that many residents, especially children, are still regularly spotted scaling the jagged Pavilion perimeter and park fences to access the greenery and recreational opportunities inside it. As a further indication of the value placed on urban green spaces, data showed that $62.4 \%$ of the respondents would be willing to pay more for a property, if that property had improved access to a quality public green space, possibly maintaining increased property response to such social concerns valuations for properties located in the vicinity of such amenities (Coat, 2015). Furthermore, 60.4\% of the respondents were willing to walk $5 \mathrm{~km}$ or more to access a quality public green space. A Phi test for preference of living within walking distance of a park and willingness to pay more for a property, because it is located closer to a park, provided an effect size of 0.261 ( $p=0.033)$, as a small to medium effect and practical significant association. In terms of particular public green space features, respondents rated the elements captured in Figure 4 as critical attributes expected from a quality public green space.

Figure 4 demonstrates that the community regarded nearly all features listed as critical, with both green attributes (grass and trees) as well as recreational elements (play equipment, sporting facilities and seating) regarded as critical by upwards of $88 \%$ of the respondents each. Whilst recreational amenities predominantly require direct physical access to realise advantages, green elements may provide at least partial advantages through visual access alone (Wire, 2015), as also provided in the preceding literature. Whilst the chain-link fencing around most playgrounds provide some visual access to the vegetation inside, the impermeable corrugated metal barrier encircling the Bridgton Pavilion obstructs virtually all views of the greenery within (Figure 5). These corrugated metal sheets, baptised by the community as 'die plate', were not replaced during the refurbishment process, as they have become intricately bound with the heritage and identity of the community, according to an interview with Westen (2013).

Whilst the heritage and cultural benefits offered to the Bridgton Pavilion by the corrugated metal wall is recognised as part of an important service delivered by the facility as a whole, there are also other concerns. The preservation of the corrugated metal wall may recall Turner's work (Turner, 1963; 1968), in endorsing an appreciation of informality as the antithesis of soulless and monotonous modernity, described by terms such as 'vernacular, innocent and authentic'. However, such romanticised conceptualisations

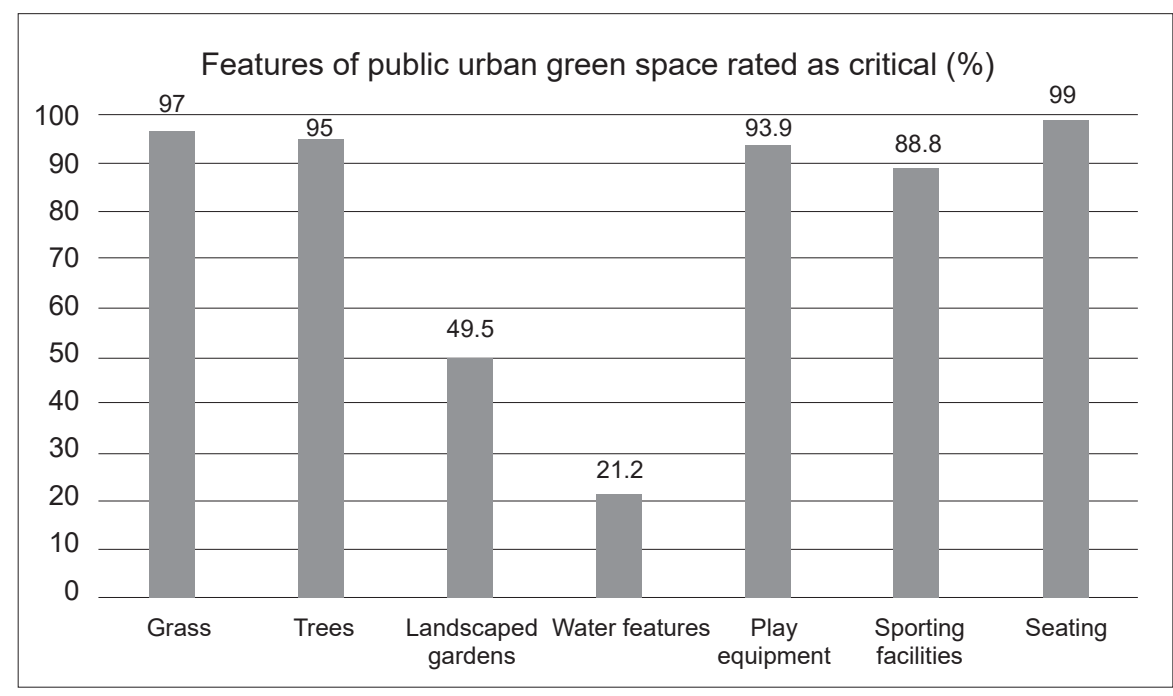

Figure 4: Features of a public green space rated as critical 
have also been condemned, notably for aestheticizing poverty (Roy \& AISayyad, 2004) and glazing over the often chaotic and violent characteristics of more informal features (Van Ballegooijen \& Rocco, 2013: 1795-1802). The landmark wall continues to create a harsh and uninviting obstruction, mirroring the informality found in the backyards of adjacent properties. Elsewhere, informal backyard rentals have been accused of "blighting the visual landscape" by introducing the unwanted aesthetics of informal settlements into formal housing areas (Lemanski, 2009: 475-476), being indicative of "backward rural life" (Robins, 2002: 541) and detracting from urban quality and dignity (Shapurjee \& Charlton, 2013: 663). The cumulative effect of the informal backyard dwellings that dot the landscape surrounding the Pavilion, often visible from the street, and 'die plate' may present adverse psychological effects, ultimately decreasing pride in the environment, further marginalising an already disadvantaged community, and deterring wealthier patrons from attending events hosted at the Pavilion.

The local authority must be applauded for the manner in which the Bridgton Pavilion refurbishment was sensitised around both community heritage and the outcomes of stakeholder engagement processes that articulated a desire to maintain 'die plate', within a development context traditionally directed at eradicating all traces of informality (Del Mistro \& Hensher, 2009: 338; Lemanski, 2009: 477; Bradlow, Bolnick \& Shearing, 2011: 272; Huchzermeyer, 2011: 3; Rubin \& Gardner, 2013: 68; Huchzermeyer, 2014: 43). Yet, the ultimate impact cannot be denied in detracting from general neighbourhood aesthetics.

In the case study, aesthetics was furthermore severely affected by incidences of littering and dumping, identified as a sign of neighbourhood decline (Marais \& Armitage, 2004: 483). Littering and dumping have become common features of life in South Africa's lower income communities (Marais, Armitage \& Pithey, 2000: 5; Marais \& Armitage, 2004: 485; Goebel, Dodson \& Hill 2010: 576), even as higher income groups tend to display a higher mean per capita waste generation rate than lower income groups (Napier, 2002: 20; Nshimirimana, 2005: 13; Oyekale, 2015: 15888). Site visits revealed severe incidences of littering from pedestrians and piles of household waste dumped mainly on marginal green spaces. In relation, questionnaire results showed that $57.1 \%$ of the respondents rated littering as a daily problem related to their nearest public green space. Gusts of wind spread litter around further and the fences surrounding public green spaces and the perimeters of some yards act as nets, catching scraps of paper and plastic, as also recognised in Dikgang,
Leiman \& Visser (2010). Waste levels are increased dramatically by the addition of consumers accommodated in informal backyard rental structures. Whilst household waste is removed by the local authority (Lategan \& Cilliers, 2016) backyard dwellings are generally not provided with additional refuse bins or liners in Oudtshoorn. As a result it is deduced that informal backyard rentals exacerbate littering and dumping challenges, in keeping with Lemanski (2009: 477); Govender (2011); Govender et al. (2011a: 339; 2011b: 29). In recognition of such challenges, the City of Cape Town, for example, distributes additional refuse bins to informal backyard tenants as part of its Backyard Essential Services Improvement Programme, expressed in an interview with Cameron (2015).

The informal construction materials that constitute the majority of informal backyard rental dwellings further levy impacts on tenants, the broader community and the environment. The timber used as construction material in the majority of informal backyard structures in the case study is generally sourced from the discarded stock of local timber yards, with most of the fragments being tarred, releasing fumes and rendering structures highly flammable, according to an interview with Daughters (2015). Informal backyard rentals have been branded as fire risks in the literature (Crankshaw et al.,

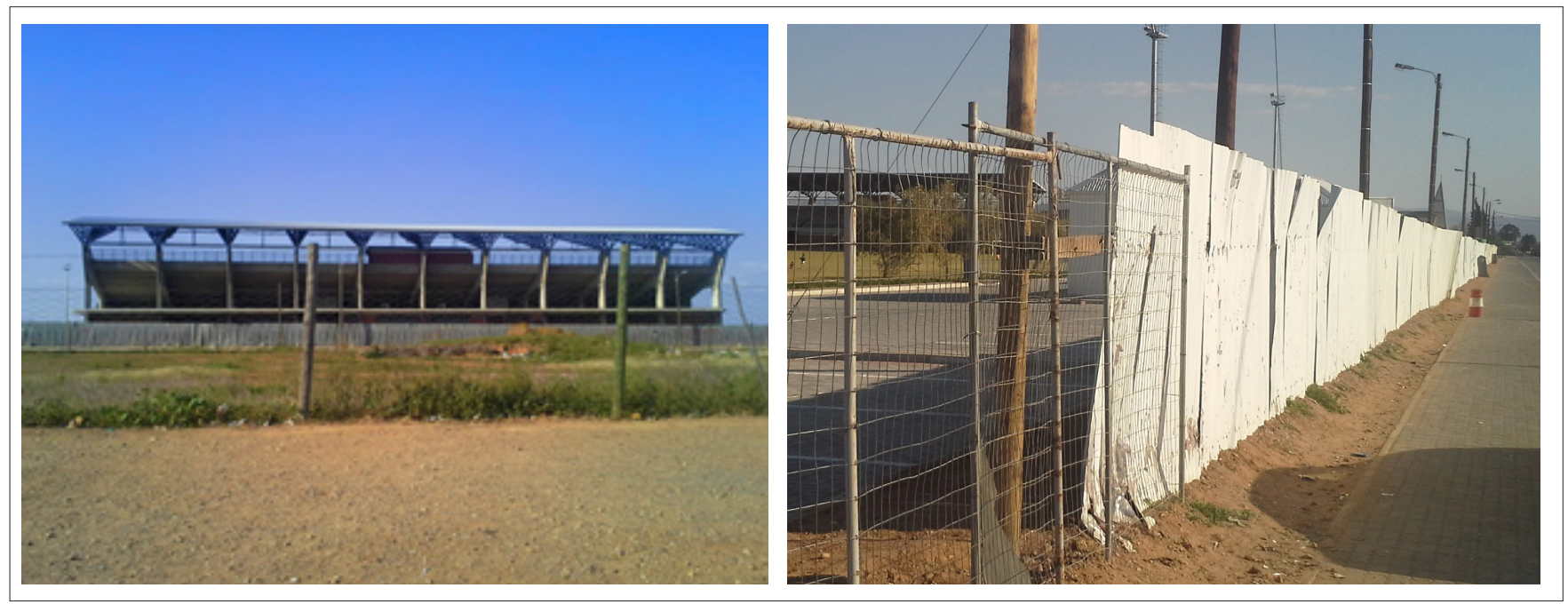

Figure 5: A view of the Bridgton Pavilion and its corrugated iron wall 
2000: 854; Bank, 2007: 206; Carey, 2009: 3; Watson, 2009: 11; Rubin \& Gardner, 2013: 43; Tshangana, 2013: 12; Shapurjee et al., 2014: 20). Structures in Bridgton/Bongolethu are no different, according to interviews with Case (2015) and Wire (2015). Fires may spread from yard to yard with vengeance, causing fatalities, damage to property, and air pollution. Public green spaces may fulfil an important function when such fires surge through a street block, providing a point of assembly and safe harbour from where collective action can be taken, provided that such spaces are open and accessible.

The following section turns the focus away from public green spaces towards the domestic scale, investigating findings on the private gardens encountered in the Bridgton/ Bongolethu case study.

\subsection{Domestic green space (private gardens) in Bridgton and Bongolethu}

Domestic gardens deliver invaluable ecosystem services (Barbosa et al., 2007: 187; Lubbe et al., 2010: 2900; Cilliers et al., 2013: 693; Mosina \& Maroyi, 2016: 189). However, the intensity of ecosystem services provided may depend heavily on the nature of the vegetation found in such spaces. Survey data showed that only $33.3 \%$ of the respondents had planted and maintained a lawn. The majority of homeowners were conceivably deterred by the significant watering and maintenance requirements related to sustaining a lawn in addition to the backyard space occupied by informal structures where lawns could be planted. Statistical analysis showed that no significant relationship could be established between perceptions of limited outside space and privacy and number of informal backyard rental structures presented per stand. However, analysis also revealed that respondents were more likely to maintain that backyarding limited their outside space and privacy, where five or more people were accommodated in main dwellings, or more than four backyard tenants were accommodated in the yard.
Where less than three backyard tenants were housed, respondents were more likely to report that backyarding did not limit their outside space and privacy. Statistical testing revealed a significant difference between feelings of limited outside space and privacy and both number of occupants in the main dwelling and number of backyard tenants. As such, perceptions on reduced outside space and privacy were related to an increased number of people in both fields. Overall, $57.5 \%$ of the respondents who accommodated informal backyard rentals were of the opinion that backyard structures on their properties limited privacy and outside space. Yet, $82.8 \%$ of all the respondents revealed that their children still played in their backyards, of which $51.8 \%$ did so frequently. Data showed that $79.2 \%$ of children used front yards to play, of which $27.5 \%$ did so frequently. Thus, domestic gardens continued to provide primary venues for play, even as small stand sizes, probable overcrowding and informal backyard densification reduced the space available for such activities.

The survey also showed that $60.6 \%$ of the respondents had planted trees, whereas $76.2 \%$ had planted some sort of shrubbery. Trees may be especially valued to provide shade in the scorching heat of a Klein Karoo summer. The gardens of $42 \%$ of the respondent properties also contained flowerbeds, realising aesthetic values, especially in front yards where they could be viewed and admired by passers-by. Furthermore, nearly two thirds (67\%) of the respondents had planted fruits and vegetables. Various authors have commented on the value of domestic gardens in producing food and income-generating opportunities, especially for vulnerable, lowincome households through such cultivations (Lindemann-Matthies \& Brieger, 2016: 33; Mosina \& Maroyi, 2016: 181). It should be noted that, although the study area displayed a diversity of plant species, it is permissible to suggest that the area remains less species rich than more affluent, generally White parts of Oudtshoorn, as noted elsewhere by
Lubbe et al. (2010: 2907) and Cilliers et al. (2013: 692). A glaring disparity is apparent in green area cover between apartheid-era townships and traditionally White suburbs mostly on the opposite side of the Grobbelaars River in Oudtshoorn (see Figure 1), further underlining differences in the number of species feasibly established.

\section{CONCLUSION}

Findings in the Bridgton/Bongolethu case study seem to disprove the 'compensation hypothesis' as an assumed increase in the use of public green space in compensation for private green space lost. The case study presented fairly small stand sizes, with outside space decreased further by informal backyard densification in over half of the respondent properties. Yet, whilst over $80 \%$ of the respondents claimed to make use of proximate public green spaces, the majority did so infrequently, not as part of their daily or even weekly routines. Statistical analysis revealed that even those respondents claiming that proximate public green spaces were always accessible, only visited these spaces about once a month. In addition, only an insubstantial number of respondents regarded public green spaces as their children's primary play locales, with the majority still playing in domestic green spaces (private gardens), in both front and backyard spaces. As such, this article concurs that public and private green spaces may have dissimilar functions and meanings and that generally public green space cannot be provided as a substitute for access to private green space (Coolen \& Meesters, 2012; Haaland \& Van den Bosch, 2015).

The insignificant association established between the number of informal backyard rental structures and perceptions of limited outside space and privacy, considered against the significant association proven between the number of informal backyard tenants and perceptions of limited outside space and privacy, further seems to downplay the impacts of informal 
backyard rental structures on reducing available yard space and the need to venture to public green spaces in compensation in the case study. Such findings are further supported by the extent of cultivation still taking place in the respondents' gardens, especially in terms of fruits and vegetables. Yet, the effects of increased population densities need to be considered and addressed and the value of accessible, quality public green spaces realised in providing places of escape from crowded yards. As such, the active use of public green spaces must be encouraged, potential ecosystem services, disservices and benefits managed, and barriers to accessibility redressed. The latter is especially evident in the case study and its fenced playgrounds and heritage-sensitive, but 'informally' enclosed Pavilion, where disservices have impeded access and detract from aesthetic quality in conjunction with the effects of informal backyard structures.

Whilst this article has provided an important preliminary investigation into a previously neglected aspect of South Africa's informal backyard rental sector, there are still numerous aspects to consider in future research related to urban green spaces. With adequate policy intervention in mind, future investigations may focus on other smaller towns and importantly on highly consolidated low-income suburbs in larger cities and metropolitan areas, where extreme informal backyard densities may realise the 'compensation hypothesis' and underscore the need to redress existing shortcomings and make adequate provision for quality public green spaces, that meet and exceed minimum requirements in new developments in anticipation of informal backyard infill. Ultimately, findings highlight the need to reconsider urban green space planning within low-cost areas in terms of accessibility, form and function as part of broader spatial planning approaches.

\section{ACKNOWLEDGEMENTS}

This research (or parts thereof) was made possible by the financial contribution of the NRF (National Research Foundation) South Africa. Any opinions, findings and conclusions or recommendations expressed in this material are those of the author(s) and therefore the NRF does not accept any liability in regard thereto.

\section{REFERENCES LIST}

BANK, L. 2007. The rhythms of the yards: Urbanism, backyards and housing policy in South Africa. Journal of Contemporary African Studies, 25(2), pp. 205-228. https://doi. org/10.1080/02589000701396298

BARBOSA, O., TRATALOS, J.A., ARMSWORTH, P.R., DAVIES, R.G., FULLER, R.A., JOHNSON, P. \& GASTON, K.J. 2007. Who benefits from access to green space? A case study from Sheffield, UK. Landscape and Urban Planning, 83, pp. 187-195. https://doi.org/10.1016/j. landurbplan.2007.04.004

BERNARDINI, C. \& IRVINE, K.N. 2007. The 'nature' of urban sustainability: Private or public green spaces. Sustainable Development and Planning III, vol. 2, pp. 661-674. https://doi. org/10.2495/SDP070642

BHATTI, M. \& CHURCH, A. 2000.

'I never promised you a rose garden': Gender, leisure and home-making. Leisure Studies, 19(3), pp. 183-197. https://doi. org/10.1080/02614360050023071

BOLUND, P. \& HUNHAMMAR, S. 1999. Ecosystem services in urban areas. Ecological Economics, 29(2), pp. 293-301. https://doi.org/10.1016/ S0921-8009(99)00013-0

BRADLOW, B., BOLNICK, J. \& SHEARING, C. 2011. Housing, institutions, money: The failures and promise of human settlements policy and practice in South Africa. Environment and Urbanization, 23(1), pp. 267-275. https://doi. org/10.1177/0956247810392272

BRUNNER, A. 2012. The effects of urban sprawl on daily life. Orangeburg, South Carolina: South Carolina State University.
BYRNE, J. \& SIPE, N. 2010. Green and open space planning for urban consolidation - A review of the literature and best practice. Brisbane, Australia: Urban Research Program, Griffith University.

CAMERON. Department of Housing, City of Cape Town. Informal backyard rental pilots in the City of Cape Town [personal interview], Cape Town, 25 February 2015.

CAPTAIN. 2013. SAPD Oudtshoorn. Personal interview on Crime in the Bridgton and Bongolethu townships, Oudtshoorn, 30 April.

CAREY, S. 2009. Investigation into the proliferation of low-income private rental housing supply, and the development of recommendations concerning appropriate interventions/ responses. (pp. 1-36): Social Housing Foundation. Urban Landmark.

CASE. 2015. Oudtshoorn Local Municipality Fire Department. Personal interview on fire risks related to informal backyard rentals in Oudtshoorn, Oudtshoorn, 30 September.

CHARLES, H. \& DUKES, J.S. 2007. Impacts of invasive species on ecosystem services. In: Nentwig, W., (Ed.). Biological invasions. Ecological Studies, no. 193. Berlin: Springer, pp. 217-237. https://doi. org/10.1007/978-3-540-36920-2_13

CHEN, W.Y. \& HU, F.Z.Y. 2015. Producing nature for public: Landbased urbanization and provision of public green spaces in China. Applied Geography, 58, pp. 32-40. https://doi. org/10.1016/j.apgeog.2015.01.007

CHOBOKOANE, N. \& HORN, A. 2015. Urban compaction and densification in Bloemfontein, South Africa: Measuring the current urban form against Mangaung Metropolitan Municipality's Spatial Planning Proposals for Compaction. Urban Forum, 26(1), pp. 77-93.

CILLIERS, E.J. \& CILLIERS, S.S. 2015. From green to gold: A South African example of valuing urban green spaces in some residential areas in Potchefstroom. Town Planning Review, Issue 67, pp. 1-12.

CILLIERS, E.J. \& CILLIERS, S.S. 2016. Planning for green infrastructure: Options for South African cities. Johannesburg: South African Cities Network. 
CILLIERS, S., CILLIERS, J., LUBBE, R. \& SIEBERT, S. 2013. Ecosystem services of urban green spaces in African countries - perspectives and challenges. Urban Ecosystems, 16(4), pp. 681-702. https://doi.org/10.1007/ s11252-012-0254-3

COAT. 2015. Oudtshoorn Local Municipality. Personal interview on the effects of informal backyard rentals on property valuation, Oudtshoorn, 7 October.

COMBER, A., BRUNSDON, C. \& GREEN, E. 2008. Using a GISbased network analysis to determine urban greenspace accessibility for different ethnic and religious groups. Landscape and Urban Planning, 86, pp. 103-114. https://doi.org/10.1016/j. landurbplan.2008.01.002

COOLEN, H. \& MEESTERS, J. 2012.

Private and public green spaces: Meaningful but different settings. Journal of Housing and the Built Environment, 27(1), pp. 49-67. https:// doi.org/10.1007/s10901-011-9246-5

COSTANZA, R., D'ARGE, R., DE GROOT, R., FARBER, S., GRASSO, M., HANNON, B., LIMBURG, K., NAEEM, S., O'NEILL, R.V., PARUELO, J., RASKIN, R.G., SUTTON, P. \& VAN DEN BELT, M. 1997. The value of the world's ecosystem services and natural capital. Nature, (6630), pp. 253-260. https://doi.org/10.1038/387253a0

CRANKSHAW, O., GILBERT, A. \& MORRIS, A. 2000. Backyard Soweto. International Journal of Urban \& Regional Research, 24(4), pp. 841. https://doi. org/10.1111/1468-2427.00282

DAILY, G.C., POLASKY, S., GOLDSTEIN, J., KAREIVA, P.M., MOONEY, H.A., PEJCHAR, L., RICKETSS, T.H., SALZMAN, J. \& SHALLENBERGER, R. 2009. Ecosystem services in decision-making: Time to deliver. Frontiers in Ecology and the Environment, 7(1), pp. 21-28. https://doi.org/10.1890/080025

DALE, A. \& NEWMAN, L.L. 2009. Sustainable development for some: Green urban development and affordability. Local Environment, 14(7), pp. 669-681. https://doi. org/10.1080/13549830903089283

DAUGHTERS. Oudtshoorn Local Municipality. Personal interview on building regulations with regard to informal backyard structures in Oudtshoorn. Oudtshoorn, 7 October.
DEAT (DEPARTMENT OF ENVIRONMENTAL AFFAIRS AND TOURISM). 2015. South Africa Environment outlook. Chapter 5: Human settlements. Department of Environmental Affairs and Tourism. Preoria. pp. 1-86.

DEL MISTRO, R.A. \& HENSHER, D. 2009. Upgrading informal settlements in South Africa: Policy, rhetoric and what residents really value. Housing Studies, 24(3), pp. 333-354. https://doi. org/10.1080/02673030902869279

DIKGANG, J., LEIMAN, A. \& VISSER, M. 2010. Analysis of the plastic-bag levy in South Africa. Policy Paper Number 18 (pp. 1-14): University of Cape Town.

DÖRNYEI, Z. 2007. Research methods in applied linguistics. New York: Oxford University Press.

\section{DURAND-LASSERVE, A. \&} ROYSTON, L. (Eds). 2002. Holding their ground: Secure land tenure for the urban poor in developing countries. London: Earthscan.

ESCOBEDO, F.J., KROEGER, T. \& WAGNER, J.E. 2011. Review: Urban forests and pollution mitigation: Analyzing ecosystem services and disservices. Environmental Pollution, 159, pp. 2078-2087. https://doi. org/10.1016/j.envpol.2011.01.010

\section{EXPLORABLE.COM. 2009.}

Convenience sampling. [online]. Available from: https://explorable.com/ convenience-sampling [Accessed: 30 October 2016].

FERGUSON, B.B.I.O. 1996. The environmental impacts and public costs of unguided informal settlement; the case of Montego Bay. Environment and Urbanization, 8(2), pp. 171-193. https:// doi.org/10.1177/095624789600800218

FRANCIS, M. 1990. The everyday and the personal: Six garden stories. In: Francis, M. \& Hester R.T. (Eds). The meaning of gardens. Cambridge: MIT Press, pp. 206-216.

GARDNER, D. 2009. Strategy for increasing supply of small-scale private dwelling rental in South Africa. Social Housing Foundation. Urban Landmark.

GEYER, H., SCHLOMS, B., DU PLESSIS, D. \& VAN EEDEN, A. 2011. Land quality, urban development and urban agriculture within the Cape Town urban edge. Town and Regional Planning, Issue 59, pp.41-52.
GILBERT, A., MABIN, A., MCCARTHY, M. \& WATSON, V. 1997. Low-income rental housing: Are South African cities different? Environment and Urbanization, 9(1), pp. 133-144. https:// doi.org/10.1177/095624789700900111

GOEBEL, A. 2007. Sustainable urban development? Low-cost housing challenges in South Africa. Habitat International, 31, pp. 291-302. https:// doi.org/10.1016/j.habitatint.2007.03.001

GOEBEL, A., DODSON, B. \& HILL, T. 2010. Urban advantage or urban penalty? A case study of femaleheaded households in a South African city. Health and Place, 16(3), pp. 573-580. https://doi.org/10.1016/j. healthplace.2010.01.002

GOVENDER, T. 2011. The health and sanitation status of specific low-cost housing communities as contrasted with those occupying backyard dwellings in the City of Cape Town. Unpublished PhD (Community Health). Stellenbosch: University of Stellenbosch

GOVENDER, T., BARNES, J.M. \& PIEPER, C.H. 2011a. Housing conditions, sanitation status and associated health risks in selected subsidized low-cost housing settlements in Cape Town, South Africa. Habitat International, 35, pp. 335-342. https://doi.org/10.1016/j. habitatint.2010.11.001

GOVENDER, T., BARNES, J.M. \& PIEPER, C.H. 2011b. The impact of densification by means of informal shacks in the backyards of low-cost houses on the environment and service delivery in Cape Town, South Africa. Environmental Health Insights, 5(5), pp. 23-52. https://doi.org/10.4137/EHI. S7112

GROSE, M.J. 2009. Changing relationships in public open space and private open space in suburbs in south-western Australia. Landscape and Urban Planning, 92, pp. 53-63. https://doi.org/10.1016/j. landurbplan.2009.02.006

GROSS, H. \& LANE, N. 2007.

Landscapes of the lifespan: Exploring accounts of own gardens and gardening. Journal of Environmental Psychology, 27, pp. 225-241. https:// doi.org/10.1016/j.jenvp.2007.04.003 
GWEDLA, N. \& SHACKLETON, C.M.

2015. The development visions and attitudes towards urban forestry of officials responsible for greening in South African towns. Land Use Policy, 42, pp. 17-26. https://doi.org/10.1016/j. landusepol.2014.07.004

HAALAND, C. \& VAN DEN BOSCH, C.K. 2015. Review: Challenges and strategies for urban greenspace planning in cities undergoing densification: A review. Urban Forestry \& Urban Greening, 14(4), pp. 760-771. https://doi.org/10.1016/j. ufug.2015.07.009

HARRISON, P., BOBBINS, K., CULWICK, C., HUMBY, T., LA MANTIA, C., TODES, A. \& WEAKLEY, J. 2014. Urban resilience thinking for municipalities: University of the Witwatersrand, Gauteng City Region Observatory.

HOCTOR, T.S., CARR, W.H., ZWICK, M.H., HUNTLEY, P.D., SMITH, D.J., MAEHR, D.M., BUCH, J \& HILSENBECK, J. 2008. Land corridors in the southeast USA: Connectivity to protect biodiversity and ecosystem services. Journal of Conservation Planning, 4, pp. 90-122.

HOFFMAN, M.T., CARRICK, P.J., GILLSON, L. \& WEST, A.G. 2009. Drought, climate change and vegetation response in the succulent karoo, South Africa: Research article. South African Journal of Science, 105(1), pp. 54-60. https://doi.org/10.1590/ s0038-23532009000100021

HOUSSAY-HOLZSCHUCH, M. \& TEPPO, A. 2009. A mall for all? Race and public space in post-apartheid Cape Town. Cultural Geographies, 16(3), pp. 351-379. https://doi. org/10.1177/1474474009105052

HUCHZERMEYER, M. 2009. The struggle for in situ upgrading of informal settlements: A reflection on cases in Gauteng. Development Southern Africa, 26(1), pp. 59-73. https://doi. org/10.1080/03768350802640099

HUCHZERMEYER, M. 2011. Cities with 'slums': From informal settlement eradication to a right to the city in Africa: Claremont, South Africa. Cape Town: UCT Press.

HUCHZERMEYER, M. 2014. Invoking Lefebvre's 'right to the city' in South Africa today: A response to Walsh. City, 18(1), pp. 41-49. https://doi.org/10.1080 /13604813.2014.868166
KABISCH, N. 2015. Ecosystem service implementation and governance challenges in urban green space planning - The case of Berlin, Germany. Land Use Policy, 42, pp. 557-567. https://doi.org/10.1016/j. landusepol.2014.09.005

KABISCH, N. \& HAASE, D. 2014. Green justice or just green? Provision of urban green spaces in Berlin, Germany. Landscape and Urban Planning, 122(February), pp. 129139. https://doi.org/10.1016/j. landurbplan.2013.11.016

KABISCH, N., QURESHI, S. \& HAASE, D. 2015. Human-environment interactions in urban green spaces - A systematic review of contemporary issues and prospects for future research. Environmental Impact Assessment Review, 50, pp. 25-34. https://doi.org/10.1016/j. eiar.2014.08.007

KILIAN, D., FIEHN, H., BALL, J. \& HOWELLS, M. 2005. Background research paper produced for the South Africa Environment Outlook report on behalf of the Department of Environmental Affairs and Tourism (pp. 3-34): SRK Consulting.

KLUG, N., RUBIN, M. \& TODES, A. 2013. Inclusionary housing policy: A tool for re-shaping South Africa's spatial legacy? Journal of Housing and the Built Environment, 28(4), pp. 667-678. https://doi.org/10.1007/ s10901-013-9351-8

KREMEN, C. \& COWLING, R. 2005. Managing ecosystem services: What do we need to know about their ecology? Ecology Letters, 8(5), pp. 468-479. https://doi. org/10.1111/j.1461-0248.2005.00751.x

LATEGAN, L.G. 2012. A study of the current South African housing environment with specific reference to possible alternative approaches to improve living conditions. Unpublished thesis (MArt et Scien). Potchefstroom: North-West University.

LATEGAN, L.G. \& CILLIERS, E.J. 2013. South Africa's informal backyard rental sector: Linkages with Smart Growth and sustainability concepts. Paper presented at the Sustainable City 2013, Putrajaya, Malaysia.

LATEGAN, L.G. \& CILLIERS, E.J. 2016. Towards more compact South African settlements through informal housing: The case of backyard densification in Bridgton and
Bongolethu, Oudtshoorn. Stads- en Streeksbeplanning / Town and Regional Planning (68), pp. 12-26.

LEE. Oudtshoorn Local Municipality. Personal interview on planning for the Rose Valley settlement. Oudtshoorn, July 2012.

LEMANSKI, C. 2009. Augmented informality: South Africa's backyard dwellings as a by-product of formal housing policies. Habitat International, 33, pp. 472-484. https://doi. org/10.1016/j.habitatint.2009.03.002

LIN, B., MEYERS, J. \& BARNETT, G. 2015. Understanding the potential loss and inequities of green space distribution with urban densification. Urban Forestry \& Urban Greening, 14(4), pp. 952-958. https://doi. org/10.1016/j.ufug.2015.09.003

LINDEMANN-MATTHIES, P. \& BRIEGER, H. 2016. Does urban gardening increase aesthetic quality of urban areas? A case study from Germany. Urban Forestry \& Urban Greening, 17, pp. 33-41. https://doi. org/10.1016/j.ufug.2016.03.010

LUBBE, C.S., SIEBERT, S.J. \& CILLIERS, S.S. 2010. Political legacy of South Africa affects the plant diversity patterns of urban domestic gardens along a socio-economic gradient. Scientific Research and Essays, 5(19), pp. 2900-2910.

LYYTIMÄKI, J. \& SIPILÄ, M. 2009. Short communication: Hopping on one leg - The challenge of ecosystem disservices for urban green management. Urban Forestry \& Urban Greening, 8(4), pp. 309-315. https://doi. org/10.1016/j.ufug.2009.09.003

LYYTIMÄKI, J., PETERSEN, L.K., NORMANDER, B. \& BEZÁK, P. 2008. Nature as a nuisance? Ecosystem services and disservices to urban lifestyle. Environmental Sciences (15693430), 5(3), pp. 161-172.

MAAT, K. \& DE VRIES, P. 2006. The influence of the residential environment on greenspace travel: Testing the compensation hypothesis. Environment \& Planning $A, 38(11)$, pp. 2111-2127. https://doi.org/10.1068/a37448

MAMBO, T. 2012. An examination of changes in rainfall, streamflow and landcover: A case study of the Kandelaars catchment, Oudtshoorn, South Africa, 1926 to 2008: University of Cape Town. 
MARAIS, M. \& ARMITAGE, N. 2004. The measurement and reduction of urban litter entering stormwater drainage systems: Paper 2 - Strategies for reducing the litter in the stormwater drainage systems. Water $S A, 30(4)$, pp. 483-492. https://doi.org/10.4314/ wsa.v30i4.5100

MARAIS, M., ARMITAGE, N. \& PITHEY, S. 2000. Proposed catchment management strategies to reduce litter loadings in South African drainage systems. Paper presented at the WISA 2000 Biennial Conference, Sun City, South Africa, 28 May-1 June, 2000.

MCCONNACHIE, M. \& SHACKLETON, C.M. 2010. Public green space inequality in small towns in South Africa. Habitat International, 34 , pp. 244-248. https://doi.org/10.1016/j. habitatint.2009.09.009

MCCONNELL, V.D.K. \& WILEY, K. 2010. Infill development: Perspectives and evidence from Economics and Planning. Discussion Paper 10-13 for Resources for the Future, May.

MCGAFFIN, R., CIROLIA, L.R. \& MASSYN, M.W. 2015. Overcoming the challenge of vertical consolidation in South Africa's low-income settlements: A case study of Du Noon. Urban Forum, Issue 26, pp. 59-75. https://doi. org/10.1007/s12132-014-9232-6

MEA (MILLENNIUM ECOSYSTEM ASSESSMENT BOARD). 2005.

Ecosystems and human well-being: A framework for assessment. A report of the conceptual framework working group of the Millennium Ecosystem Assessment. Washington, DC: Island Press.

MORANGE, M. 2002. Backyard shacks: The relative success of this housing option in Port Elizabeth. Urban Forum, 13(2), pp. 3-25.

MOSINA, G.K.E. \& MAROYI, A. 2016. Edible plants of urban domestic gardens in the Capricorn District, Limpopo Province, South Africa. Tropical Ecology, 57(2), pp. 181-191.

NAPIER, M. 2002. Informal settlement integration, the environment and sustainable livelihoods in sub-Saharan Africa. In: Proceedings of Improving Post-Disaster Reconstruction in Developing Countries, 23-25 May, Montreal, Canada: University of Montreal, pp. 28-47.
NOLON, J.R. 2016. Enhancing the urban environment through green infrastructure. Environmental Law Reporter: News \& Analysis, 46(1), pp. 10071-10086.

NSHIMIRIMANA, J. 2005. Attitudes and behaviour of low-income households towards the management of domestic solid waste in Tafelsig, Mitchell's Plain. Unpublished MADevStud, University of the Western Cape: Institute of Social Development.

ODINDI, J.O. \& MHANGARA, P. 2012. Green spaces trends in the city of Port Elizabeth from 1990 to 2000 using remote sensing. International Journal of Environmental Research, 6(3), pp. 653-662.

OYEKALE, A.S. 2015. Factors explaining households' cash payment for solid waste disposal and recycling behaviors in South Africa. Sustainability, 7(12), pp. 15882-15899. https://doi.org/10.3390/su71215795

POULSEN, L. \& SILVERMAN, M. 2005. Design strategies for the densification of low-income housing. International Journal for Housing Science and Its Applications, 30(1 SPEC. ISS.), pp. 19-31.

ROBINS, S. 2002. Planning 'suburban bliss' in Joe Slovo Park, Cape Town. Africa, 72(4), pp. 511-548. https://doi. org/10.3366/afr.2002.72.4.511

ROY, A. \& ALSAYYAD, N. (Eds). 2004. Urban informality: Transnational perspectives from the Middle East, Latin America, and South Asia: UK, Oxford: Lexington Books.

RSA (REPUBLIC OF SOUTH AFRICA). 1994. White Paper on the Reconstruction and Development Programme (RDP). Government Gazette: No. 16085, 23 November. Cape Town: Government Printer.

RSA (REPUBLIC OF SOUTH AFRICA) 2004. Department of Human Settlements. Breaking new ground - A comprehensive plan for the development of sustainable human settlements (pp. 3-28).

RUBIN, M. \& GARDNER, D. 2013. Developing a response to backyarding for SALGA (pp. 1-93).

RUPPRECHT, C.D.D. \& BYRNE, J.A. 2014. Review: Informal urban greenspace: A typology and trilingual systematic review of its role for urban residents and trends in the literature. Urban Forestry \& Urban Greening, 13, pp. 597-611. https://doi.org/10.1016/j. ufug.2014.09.002
SHAPURJEE, Y. \& CHARLTON, S. 2013. Transforming South Africa's low-income housing projects through backyard dwellings: Intersections with households and the state in Alexandra, Johannesburg. Journal of Housing and the Built Environment, 28(4), pp. 653-666. https://doi.org/10.1007/ s10901-013-9350-9

SHAPURJEE, Y., LE ROUX, A. \& COETZEE, M. 2014. Backyard housing in Gauteng: An analysis of spatial dynamics. Stads- en Streekbeplanning / Town and Regional Planning, Issue 64 , pp. $19-30$.

SIVAM, A. \& KARUPPANNAN, S. 2012. Density design and sustainable residential development. In: Lehmann, S. \& Crocker R. (Eds). Designing for zero waste: Consumption, technlogies and the built environment. New York: Earthscan, pp. 267-283.

STATSSA (STATISTICS SOUTH AFRICA). 2014. Statistics South Africa: General Household Survey 2014.1-174.

TENGBERG, A., FREDHOLM, S., ELIASSON, I., KNEZ, I., SALTZMAN, K. \& WETTERBERG, O. 2012. Cultural ecosystem services provided by landscapes: Assessment of heritage values and identity. Ecosystem Services, 2, pp. 14-26. https://doi. org/10.1016/j.ecoser.2012.07.006

TSHANGANA, A. 2013. Local government position on municipal responses to backyarders and backyard dwellings. Draft Policy Proposal. (pp. 1-17). South African Local Government Association.

TURNER, J.F.C. 1963. Dwelling resources in South America. Architectual Design, 8(August), pp. 360-393.

TURNER, J.F.C.1968. The squatter settlement: Architecture that works. Architectual Design, 38(August), pp. 355-360.

TUROK, I. 2013. Transforming South Africa's divided cities: Can devolution help? International Planning Studies, 18(2), pp. 168-187. https://doi.org/10.10 80/13563475.2013.774146

TUROK, I. \& BOREL-SALADIN, J. 2014. Is urbanisation in South Africa on a sustainable trajectory? Development Southern Africa, 31(5), pp. 675-691. https://doi.org/10.1080/037683 5X.2014.937524 
TUROK, I. \& BOREL-SALADIN, J.

2015. Backyard shacks, informality and the urban housing crisis in South Africa: Stopgap or prototype solution? Housing Studies, 16, pp. 1-26.

TZOULAS, K., KORPELA, K., VENN, S., YLI-PELKONEN, V., KAŹMIERCZAK, A., NIEMELA, J. \& JAMES, P. 2007. Review: Promoting ecosystem and human health in urban areas using Green Infrastructure: A literature review. Landscape and Urban Planning, 81(3), pp. 167-178. https://doi.org/10.1016/j. landurbplan.2007.02.001

VAN BALLEGOOIJEN, J. \& ROCCO, R. 2013. The ideologies of informality: Informal urbanisation in the architectural and planning discourses. Third World Quarterly, 34(10), pp. 1794-1810. https://doi.org/10.1080/ 01436597.2013.851890

VON DÖHREN, P. \& HAASE, D. 2015. Ecosystem disservices research: A review of the state of the art with a focus on cities. Ecological Indicators, 52, pp. 490-497. https://doi. org/10.1016/j.ecolind.2014.12.027

WAN, C. \& SHEN, G.Q. 2015. Salient attributes of urban green spaces in high density cities: The case of Hong Kong. Habitat International, 49, pp. 92-99. WARD, C.D., PARKER, C.M. \&

SHACKLETON, C.M. 2010. The use and appreciation of botanical gardens as urban green spaces in South Africa. Urban Forestry \& Urban Greening, 9, pp. 49-55.

WARD-THOMPSON, C. 2002. Urban open space in the $21^{\text {st }}$ century. Landscape and Urban Planning, 60(2), pp. 59-72. https://doi.org/10.1016/ S0169-2046(02)00059-2

WATSON, V. 2009. Strategic literature assessment for informal rental research project. Report to the Social Housing Foundation. University of Cape Town: School of Architecture, Planning and Geomatics, pp. 1-26.

WESTEN. Oudtshoorn Local Municipality. Personal interview on Planning for the Bridgton Pavilion and informal backyard rentals in Oudtshoorn. Oudtshoorn, 14 August.

WIRE. Oudtshoorn District Hospital. Personal interview on the health of informal backyard landlords and tenants in Oudtshoorn. Oudtshoorn, 6 October 2015.
WISNER, B., PELLING, M., MACARENHAS, A., HOLLOWAY, A., NDONG, B., FAYE, P., RIBOT, J. \& SIMON, D. 2015. Small cities and towns in Africa: Insights into adaptation challenges and potentials. In: Pauleit, S., Coly, A., Fohlmeister, S., Gasparini, P., Jørgensen, G., Kabisch, S., Kombe, W.J., Lindley, S., Simonis, I., Yeshitela, K. (Eds). Urban vulnerability and climate change in Africa, future city. Series 4. Luzern, Switzerland: Springer International Publishing Switzerland, pp. 153-196. https://doi. org/10.1007/978-3-319-03982-4_5

YOU, H. 2016. Characterizing the inequalities in urban public green space provision in Shenzhen, China. Habitat International, 56, pp. 176-180. https:// doi.org/10.1016/j.habitatint.2016.05.006

ZWAIG, P.J. 2015. Everyday hazards and vulnerabilities amongst backyard dwellers: A case study of Vredendal North, Matzikama Municipality, South Africa. Jàmbá: Journal of Disaster Risk Studies, 7(1), pp. 1-8. https://doi. org/10.4102/jamba.v7i1.210 